\title{
Convergence vs. Divergence Learning Style Study of Critical Thinking
}

\author{
Damajanti Kusuma Dewi, Danang Tandyonomanu \\ Universitas Negeri Surabaya \\ Surabaya, Indonesia \\ damajantikusuma@unesa.ac.id
}

\begin{abstract}
This study aims to examine the relationship of learning style to critical thinking skills in the higher education students. In this study, the Kolb Learning Style Inventory is used to determine learning styles while Watson Glasser Critical Thinking Appraisal is used to measure critical thinking. The subjects of the study were 154 students, coming from the students of the class of 2017. The data were analyzed using a t-test. The result is that is there a difference in critical thinking skills between convergent and divergent learning styles, where the critical thinking skills score in the convergent group is higher than critical thinking score in the diverging group, although most students have divergent learning styles.
\end{abstract}

Keywords-convergent learning style, divergent learning style, critical thinking skills

\section{INTRODUCTION}

Critical thinking skills are one of the skills required of graduates in the 21 st century [1]-[5]. Some experts say that critical thinking skills are required by college graduates to be able to withstand the challenges of the 21 st century; able to meet the demands of globalization; able to deal with and solve social, scientific and practical problems effectively, and able to contribute as citizens [6]-[10].

Students who have the skills of critical thinking have a provision to face the demands of the 21 st century because they are learners who think critically apply the systematics of critical thinking when dealing with the environment. The characteristics of learners who think critically is to seek information and ask for clarity of information; selects incoming information making it more critical when getting information that is sometimes less accurate; focus on the problem, so as to find the core of the problem; find solutions to problems encountered; dare to prove the solution that has been taken; able to evaluate solutions and solution results have been taken; and dare to express an opinion [11][7].

Critical thinking skills include five skills, namely: interpreting, analyzing, evaluating, drawing conclusions and explaining the results of thought [12]. Each learner uniquely receives the instructional material, which shows how learners learn [13]. According to Snipes (2007), the way in which individuals learn or retrieve information is called a learning style. Learning styles refer to how individuals organize information and present information [14]. This means that each learner has a way to learn, that is, enter information, process and organize information and present information.

According to Abdi [15], that learning style is the same as thinking style. One characteristic of critical thinking is logical thinking, analytical thinking and conclusion [16], in which each learner has a different way of doing it. Some studies support the influence of thinking style or learning by critical thinking [17], [18].

In the process of critical thinking, which learning style is the most influential? Critical thinking is a thought process that requires the ability to understand every decision taken. Pebelajar will always evaluate the stages of the activities that have been taken, in this case, the learners are required to focus on something. Therefore, learning styles more influential on the success of critical thinking is a learning style that gives the learners the opportunity to focus on all the decisions that have been taken. The convergence learning style gives the effect of thinking higher than divergent [19].

Therefore, the need for research that aims to find the difference critical thinking skills regarding learning style (diverging with convergent).

\section{METHOD}

\section{A. Participant}

The subjects of this study are students of the Faculty of Education, who programmed the course of Educational Psychology. The sampling technique used is random cluster sampling, which comes from majoring in out-of-school education and majoring in curriculum and educational technology. The total number of students involved in this study as many as 154 people.

\section{B. Instruments Penelitian}

There are two research instruments used in this study, namely:

\section{1) $W G C T A$}

WGCTA is one of the most commonly used tests for measuring CTS [20]-[22] says that this test is the most commonly used test. This test consists of 5 subtests, including Test Inference, consisting of 4 items; Test Recognition of Assumption, consisting of 4 items; Test Deduction, consists of 
3 items; Test Interpretation, consisting of 3 items; Test Evaluation of Argument, consisting of 3 items.

\section{2) Learning Style Inventory}

Kolb developed LSI to assess an individual's learning tendency. This is a short questionnaire, which evaluates how people handle new ideas and everyday situations. It is designed to measure the strengths and weaknesses of the learner by asking him to rank in a series of four different caption phrases shown in the image above. The sum is summed for each column, and this represents the relative emphasis of respondents on different learning phases[23] The reasons for choosing LSI are: LSI is often used, both in management and educators [24][25], can be applied in adult learners [25]; and Kolb's Learning Style Inventory (KLSI) is an instrument used to determine an individual's learning style [23]. It was found to be dominant in higher education as the most frequently reported instrument in a wide-ranging review of articles on the application of styles within education [26]

\section{Analisis Data}

Statistics such as means, standard deviations, and t-test, were used for determining and explaining relationships among variables

\section{RESULT AND DISCUSSION}

Based on the data analysis, it is found that there are differences in critical thinking skills between groups who have divergent learning styles with groups that have a convergent learning style. In this case, groups with convergent learning styles acquire higher critical thinking skills scores than those with divergent learning styles.

Table 1. Descriptive

\begin{tabular}{ccccc}
\hline $\begin{array}{c}\text { Learning } \\
\text { Style }\end{array}$ & $\mathrm{N}$ & Mean & $\begin{array}{c}\text { Std. } \\
\text { Deviation }\end{array}$ & $\begin{array}{c}\text { Std. Error } \\
\text { Mean }\end{array}$ \\
\hline Divergent & 108 & 9.2685 & 1.45079 & .13960 \\
Convergent & 46 & 11.7391 & 1.91410 & .28222 \\
\hline
\end{tabular}

Table 2. t-test Analysis

\begin{tabular}{lccccccccc}
\hline & $\mathrm{F}$ & Sig. & $\mathrm{t}$ & $\mathrm{df}$ & $\begin{array}{c}\text { Sig. } \\
(2-\end{array}$ & $\begin{array}{c}\text { Mean } \\
\text { Diff. } \\
\text { tailed) }\end{array}$ & $\begin{array}{c}\text { Std. } \\
\text { Error }\end{array}$ & $\begin{array}{c}95 \% \text { Confidence } \\
\text { Interval of the } \\
\text { Difference }\end{array}$ \\
& & & & & & & & & \\
Diff. & & & \\
Lower & Upper \\
\hline $\begin{array}{l}\text { Equal } \\
\text { variance } \\
\text { assumed }\end{array}$ & 5.08 & .026 & -8.759 & 152 & .000 & -2.470 & .282 & -3.027 & -1.813 \\
$\begin{array}{l}\text { Equal } \\
\text { variances } \\
\text { not } \\
\text { assumed }\end{array}$ & & & & & & & & & \\
\hline
\end{tabular}

Learning styles relate to the way learners gain information and manage information [27]. Learning styles are the attributes or trends that a person picks with learners, dealing with preferred learning options [28]. Learning styles are influenced by several variables including gender, age and course [29]; personality, personal goals, intelligence, biological rhythms or learning environment [30].

Learning styles of interest of this research subjects are divergent. Based on the clumps of science, the subject of research is a student of the Faculty of Education Unesa, which based on the clumps of science into the group of educational science. In contrast to the results of the above research, students from the arts, history, psychology and literature departments prefer divergent learning styles[23], dentistry students [31]. The differences in the results of the above studies, proving that learning styles are flexible [29], are not related to the selected courses or courses.

Convergence Learning learners through problem-solving, decision making and application of ideas; focus on logical and analytical thinking; perform activities directly [29], [32], they are interested in solving the problem [27], through actual or abstract based testing [33]. Therefore convergent learners prefer to process information directly through ideas that are symbolized in mind and modified through real behavior, preferring to work in engineering [29].

In contrast, learners of divergence learn through: imaginative ability and awareness of meaning and value, viewing concrete situations from many perspectives and then regulating many relationships into meaningful gestalt, lateral thinking is productive or imaginative, allowing emotions and intellect freedom to explore possibilities, awareness meaning, and values, beginning with a known, interactive educator. Hence divergent learners prefer to deal directly with information, observe, prefer to understand rather than do direct, directly involved with the knowledge gained [29][34].

Based on the characteristics of the two learning styles above, the convergent learning style is the learning style needed to perform critical thinking. Convergent learners tend to construct knowledge independently [35]. Construction of knowledge is needed when learners seek answers to problems that have not been previously known. The convergent learning style is a learning style that can be trained to be skilled in critical thinking [36].

Pashler [37] says that learning styles represent a way that learners prefer to process and use information received during learning, where this learning style is formed from the interaction between internal and external factors. Carol [38] says that some essential elements accompany the process of formation of learning styles, including psychological elements, biological elements, social context and conditions in which the process of learning. Besides these elements, Carol added that the relationship between learners with tasks received while learning also affects the formation of learning styles.

Cognitive theory has served as a foundation for the development of several models of learning styles and has begun a growing emphasis in education on the development of critical thinking skills. He believes that cognitive learning 
styles affect the effectiveness of the learning process. Learners who are trying to prepare their students to practice competent practice [39] therefore, benefit from identifying their learners 'cognitive learning styles and finding ways to harness that knowledge to help improve their students' critical thinking skills. Keahey and Goldgar's opinion above emphasizes that if a learner knows the learning style of the learners and provides the right stimulation, then critical thinking skills will increase. The more stimulation to activate, the higher the increase in critical thinking[40].

\section{REFERENCES}

[1] S. Asonitou, "Employability Skills in Higher Education and the Case of Greece," Procedia - Soc. Behav. Sci., vol. 175, hal. 283-290, 2015.

[2] C. L. Scott, "The Futures of Learning 2 : What Kinds of Learning for the 21 st Century," 2015.

[3] J. Mandell et al., "Service Learning as Social Change: Does Higher Education Have a Large Purpose?," Curr. Teach. Learn., vol. 7, no. 1, hal. 1-5, 2014.

[4] N. Liza, W. Karomiah, dan W. Abdullah, "Would Problem-Based Learning Affect Students' Generic Competencies?," African J. Educ. Technol., vol. 1, no. 3, hal. 1-14, 2011.

[5] KQED News/MindShift, "The Role of Metacognition in Learning and Achievement," 2016.

[6] T. A. Wagner, "Critical Thinking: The Development of a New Measure," J. Chem. Inf. Model., vol. 53, no. 9, hal. 1689-1699, 2013.

[7] J. C. Kaufman, S. B. Kaufman, dan J. A. Plucker, "Contemporary Intelligence eories of," hal. 3-14, 2012.

[8] D. Shakirova, "Technology for the Shaping of College Students' and Upper-Grade Students' Critical Thinking," Russ. Educ. Soc., vol. 49, no. 9, hal. 42-52, 2007.

[9] S. Zivkovic, "A Model of Critical Thinking as an Important Attribute for Success in the 21st Century," Procedia - Soc. Behav. Sci., vol. 232, no. April, hal. 102-108, 2016.

[10]G. ten Dam dan M. Volman, "Critical thinking as a citizenship competence: teaching strategies Critical thinking as a citizenship competence: teaching strategies," Learn. Instr., vol. 14, hal. 359-379, 2004.

[11]S. Yorganci, "Critical Thinking Dispositions of Pre-Service Mathematics Teachers," Particip. Educ. Res., vol. 3, no. 3, hal. 36-46, 2016.

[12]P. A. Facione, "Critical Thinking: A Statement of Expert Consensus for Purposes of Educational Assessment and Instruction Executive Summary “The Delphi Report," he Calif. Acad. Press, vol. 423, hal. 1-19, 1990.

[13] G. Hwang, H. Sung, C. Hung, dan I. Huang, "A Learning Style Perspective to Investigate the Necessity of Developing Adaptive Learning Systems," Educ. Technol. Soc., vol. 16, no. 2, hal. 188-197, 2013.

[14] L. E. Reed, M. Ed, R. W. Newsom, dan G. Pasco, "Determining the relationship between motivation and academic outcomes among students in the health professions.," 2007.

[15] A. Abdi, "A Study on the Relationship of Thinking Styles of Students and Their Critical Thinking Skills," Procedia - Soc. Behav. Sci., vol. 47, hal. 1719-1723, 2012.

[16]R. J. Sternberg, "Intelligence as Developing Expertise," Contemp. Educ. Psychol., vol. 24, no. 4, hal. 359-375, 1999.

[17]L.-F. Zhang, "Contributions of Thinking Styles to Critical Thinking Dispositions," J. Psychol. Interdiscip. Appl., vol. 137, no. 6, hal. 517544 , Nov 2003

[18] S. C. Yang dan W. C. Lin, "The Relationship among Creative, Critical Thinking and Thinking Styles in Taiwan High School Students.pdf," J.
Instr. Psychol., vol. 31, no. 1, 2004

[19]B. Hajesfandiari, A. G. Mehrdad, dan L. Karimi, "Comparing the Effects of Convergent and Divergent Teaching Methods on Using Articles by Iranian EFL Learners," vol. 1, no. 1, hal. 313-327, 2014.

$[20]$ K. Possin, "Critique of the Watson-Glaser Critical Thinking Appraisal Test: The more you know, the lower your score," Informal Log., 2014.

[21] M. H. M. Cheng dan Z. H. Wan, "Exploring the Effects of Classroom Learning Environment on Critical Thinking Skills and Dispositions: A Study of Hong Kong 12th Graders in Liberal Studies," Think. Ski. Creat., hal. 1-39, 2017.

[22]D. T. Tiruneh, A. G. Weldeslassie, A. Kassa, Z. Tefera, M. Cock, dan J. Elen, "specific and domain-general critical thinking skills," Educ. Technol. Res. Dev., vol. 64, no. 3, hal. 481-505, 2016.

[23] S. Lin dan Y. Lin, "A Study of Kolb Learning Style on Experiential Learning," hal. 2-5, 1984.

[24] C. I. Barmeyer, "Learning styles and their impact on cross-cultural training: An international comparison in France, Germany, and Quebec," Int. J. Intercult. Relations, vol. 28, no. 6, hal. 577-594, 2004.

[25]E. Yanardöner, Z. Kiziltepe, F. N. Seggie, dan S. A. Sekerler, "The learning styles and personality traits of undergraduates: A case at a state university in Istanbul," Anthropologist, 2014.

[26]I. Watts, Niall (University College Dublin, "The Relationship between Learning Style and Reflection in Student Blogs," Reflecting Educ., 2014.

[27]Y. Dilekli, "The Relation between Critical Thinking Skills and Learning Styles of Gifted Students," Eur. J. Educ. Stud., vol. 3, no. 4, hal. 69-96, 2017.

[28] G. P. Kra dan K. D. Arbuthnott, "Perceptual Learning Style and Learning Proficiency: A Test of the Hypothesis," vol. 98, no. 1, hal. 238-246, 2006.

[29]R. Amir dan Z. Mohd, "Teaching and Learning Styles in Higher Education Institutions : Do They Match?," Procedia - Soc. Behav. Sci., vol. 7, no. C, hal. 680-684, 2010.

[30]C. Quinn, M. E. Burbach, G. S. Matkin, dan K. Flores, "Critical Thinking for Natural Resource, Agricultural, and Environmental Ethics Education," J. Nat. Resour. Life Sci. Educ., vol. 38, hal. 221-227, 2009.

[31]D. a. ALQahtani dan S. M. Al-Gahtani, "Assessing Learning Styles of Saudi Dental Students Using Kolb's Learning Style Inventory,” J. Dent. Educ., vol. 78, no. 6, hal. 927-933, 2014

[32]D. A. Kolb, "Experiential learning: experience as the source of learning and development," no. 1984, 2006.

[33]C. C. Clark, "Student Growth in Asynchronous Online Environments : Learning Styles and Cognitive Development," no. 1984, 2012.

[34]Y. Chen, "Linking Learning Styles and Learning on Mobile Facebook," vol. 16, no. 2, hal. 94-114, 2015.

[35]Z. Kablan dan S. Kaya, "Preservice Teachers ' Constructivist Teaching Scores Based on Their Learning Styles," Aust. J. Teach. Educ., vol. 39, no. 12,2014

[36]F. Fattahi dan H. R. Haghverdi, "Does Inquiry-Based Learning Enhance Students Critical Thinking_A Case of Iranian EFL Learners," Int. J. Lang. Learn. Appl. Linguist. World Vol., vol. 9, no. 3, hal. 134-141, 2015.

[37]H. Pashler, M. Mcdaniel, D. Rohrer, dan R. Bjork, "Concepts and Evidence," vol. 9, no. 3, hal. 105-119, 2009.

[38] C. C. Wang dan K. M. Greenwood, "Chinese nursing students' culturerelated learning styles and behaviors: A discussion paper," Int. J. Nurs. Sci., vol. 2, no. 3, hal. 253-258, 2015.

[39]G. Kearsley, "Explorations in learning \& instruction: The theory into practice database," Standford, hal. 56, 2003.

[40] N. Lowy, "Learning Styles, Critical Thinking Aptitudes, and Immersion Learning in Physician Assistant Students," 2013. 